\title{
TECHNOLOGICAL SUPPORT FOR THE SYSTEM \\ OF FORMATION OF THE FUTURE HEAD \\ OF THE COMPREHENSIVE EDUCATIONAL INSTITUTION \\ TO STRATEGIC MANAGEMENT \\ IN THE MASTER'S DEGREE CONDITIONS
}

\section{Lebid Olga ${ }^{1}$ \\ Lesik Anzhelika²}

DOI: http://dx.doi.org/10.30525/978-9934-571-27-5_25

\begin{abstract}
The research considers the problem of technological support of the process of formation of readiness of the future head of the comprehensive educational institution for strategic management in the master's degree conditions. The subject of the study are the theoretical foundations of technological support for the system of forming the readiness of the future heads of comprehensive educational institutions for strategic management in the master's degree conditions. The purpose of the article is to clarify the importance of dialogic, debatable, simulation training and information-distance learning technologies in the process of forming the readiness of the future head of a comprehensive educational institution for strategic management in the conditions of a master's program. According to the goal, the following tasks were set: to characterize the essence, components and advantages of the use of pedagogical technologies that contribute to the formation readiness of the future head of a comprehensive educational institution's for strategic management in the master's degree conditions, namely dialogic, debatable, simulation training and information-distance learning technologies.

The research determines that the main pedagogical technologies of forming the readiness of the future head of a comprehensive educational institution for strategic management in the master's degree conditions are dialogic and debatable technologies (problem lecture, lecture with pre-planned mistakes, lecture-conference, lecture-press conference, lecture-conversation, lecture-brief-
\end{abstract}

\footnotetext{
${ }^{1}$ Candidate of Pedagogical Sciences, Assistant Professor,

Doctoral Student at Department of Pedagogy and Psychology,

Alfred Nobel University, Ukraine

${ }^{2}$ Candidate of Pedagogical Sciences,

Associate Professor at Department of Pedagogy,

Berdyansk State Pedagogical University, Ukraine
} 
ing, lecture with the analysis of specific situations), debatable technologies (debates, discussion, round table, expert group meetings, forum, "aquarium", "brainstorming", synectics), simulation training technologies (role-playing games, business games, training, internships (with the execution of an official role)), non-gaming technologies (case-method (method of concrete situations), "balint session", diary method, method 6-6, method of time constraints, method of sudden prohibitions, method of new variants, the method of absurd)), information-distance technologies (design topics, Internet-oriented technologies (mentoring, pair learning, e-mail, chat technology, webinar)).

The following advantages of the dialogic-debatable learning technologies are defined: the ability to generate new ideas, creative thinking, the ablitity to work with information competently (ability to collect, process, analyze); formation of quality to put forward hypotheses, to formulate problems; formation of the ability to communicate in different social groups; ability to work collectively, to prevent conflict situations or to be able to professionally solve them. The expediency of simulation training learning technologies, which simulate the real activity of the head of a comprehensive educational institution and ensure the formation of professional management skills in an artificially created environment, is substantiated. The advantages of information and distance technologies for the formation of the readiness of the future head of a comprehensive educational institution for strategic management, which provide educational and professional interaction in the system "teacher - student - computer", have been proved. It is established that the above-mentioned technologies contribute to: the formation of motives, which are adequate to the goals and objectives of management activities in the field of strategic management; effective understanding by future leaders of comprehensive educational institutions of a set of knowledge about the essence and peculiarities of strategic management; formation of business-forecasting, diagnostic-analytical, administrative-managerial and reflexive-regulatory administrative skills; the formation of personal qualities that contribute to successful strategic management (persistence, predisposition to risk, assertiveness, adaptability, pushfulness, ability to reflect).

\section{Introduction}

The relevance of the study is due to the fact that at the current stage of reforming the system of general secondary education in Ukraine, the problem of ensuring the advanced, strategic nature of education is urgent, which 
testifies the necessity of transition to a new kind of management - strategic. Strategic management provides an opportunity to predict possible changes and future trends in the development of a comprehensive educational institution, monitoring and forecasting external conditions in order to model organizational changes that ensure optimal functioning and sustainable development of educational institution. For the successful implementation of educational activities, heads of educational institutes must successfully identify and formulate strategies for the development of the educational institution. This will allow timely response to external and internal changes within an educational institution environment, and as a result of this comprehensive educational institution will function and develop in the long run.

The existing practice of preparing future heads of comprehensive educational institutions in the magistracy, its content and forms do not allow to provide the necessary level of their readiness for strategic management. In connection with this, there is a need to modernize the professional training of future heads of comprehensive educational institutions through the profound mastery of the basics of strategic management, namely the awareness of the future leaders of educational institutions of purpose and objectives of strategic management; the formation of the skills of future managers to implement the conceptual ideas of strategic management, to implement the mission and vision of the development of a comprehensive educational institution, to carry out strategic planning and to design the long-term activity of a comprehensive educational institution, to develop alternative ways of developing a comprehensive educational institution, to make well-balanced strategic decisions with a clear and thought-out mechanism for their implementation; the motivation of a positive attitude towards the use of ideas of strategic management in the system of values of the head of the institution. It is these professionals who need to help the comprehensive educational institution survive and reach its goal in the long run.

The purpose of the article is to find out the significance of dialogic-debatable, simulation training and information-distance learning technologies in the process of forming the readiness of the future head of a comprehensive educational institution for strategic management in the master's degree conditions.

According to the goal, the following task was set: characterize the essence, components and benefits of the use of pedagogical technologies that contribute to the formation of the readiness of the future head of a comprehensive educational institution for strategic management in the mas- 
ter's degree conditions, namely: dialogic-debatable, simulation training and information-distance learning technologies.

The analysis of various sources showed that in the pedagogical science considerable attention is paid to the problem of formation of the readiness of the head of the educational institution for management activities (V. Bereka, O. Dzhureliuk, H. Dmytrenko, H. Yelnykova, L. Kalinina, V. Klachko, A. Klimova, O. Kolosovych, V. Luniachek, V. Maslov, L. Onofriichuk, T. Sorochan, V. Ulich and others). But studies that emphasized the formation of the readiness of the future head of a comprehensive educational institution for strategic management and the effectiveness of the use of dialogic-debatable, simulation training and information-distance learning technologies were not found in this process. However, the problem of the use of dialogic-debatable (N. Volkova, L. Zazulina, O. Liubchenko, N. Salatska, T. Shepelenko, etc.), simulation training (E. Bocharova, I. Britchenko, I. Demchenko, H. Lavrentiev, N. Lavrentieva, A. Motsa, T. Mukhina, N. Nieudakhina, V. Strelnikov, E. Trushina, etc.), information-distance (Iu. Zhyliaieva, I. Zakharova, S. Kozhushko, S. Nakhod, V. Osadchyi, O. Pekhota, H. Selevko, S. Sysoieva, etc.) technologies in the process of professional training of future specialists and for today is of interest for the researchers both in the theoretical and methodological aspects.

The logic of the study presupposes: consideration of the advantages and the peculiarities of the use of dialogic and debatable technologies of training in the process of forming the readiness of the future head of a comprehensive educational institution for strategic management in the master's degree conditions; characteristics of the specificity of simulation training (gaming and non-gaming) learning technologies that are aimed at developing and consolidating of managerial skills that provide effective strategic management; substantiation of the essence of information-distance learning technologies, which allow to intensify the independent work of future leaders of comprehensive educational institutions in the master's degree conditions.

\section{Dialogic-debatable learning technologies}

With the purpose of forming the readiness of the future head of a comprehensive educational institution for strategic management in the master's degree conditions, the intensification of the training process, the elimination of the relative passivity of the masters, it is expedient to consider introduction of innovative training sessions with the use of such dialogic-de- 
batable technologies: problem lecture, lecture with pre-planned mistakes, lecture-conference, lecture-press conference, lecture-conversation, lecture-briefing, lecture on the analysis of specific situations that transform study in the sphere of intersubjectivity.

In today's educational environment, the process of transferring knowledge by a teacher with the help of a monologue is outdated. The logic of a monologue involves typical and only form of communication that excludes doubt and choice, discussion with oneself and the teacher, an understanding of profound changes in the scientific and spiritual life. Monologism, the orientation on the ready answers to all the questions, pronounced expressiveness of the statements are frankly negative characteristics of pedagogical activity. The nature and content of the dialogue, on the contrary, organically corresponds to the essential characteristics of pedagogical activity, its humanistic, creative nature. In addition, practically mastering the culture of the own thinking is possible only in the direct discovery of the level of this culture, which occurs in the process of dialogue [10, p. 11].

The essence of the concept of "dialogue" (derived from Greek "conversation"), H. Selevko interprets as "a form and means for the exchange of information, personal opinions and values" [8, p. 90]. Dialogue as a form of interaction not only allows the transfer of information from the subject to the subject, but also acts as a factor and incentive for the formation of personal meanings of the participants in the dialogue, for the achievement of the mutual understanding.

The main purpose of dialogic-debatable technologies is that in the process of dialogic communication, magistracy students are looking for different ways to express their own thoughts, for the development and advocacy of new values. According to N. Volkova, the introduction of dialogic-debatable technologies transforms the educational process into co-education, mutual learning (collective, group, studying in cooperation), where a student and teacher are equal, equally significant subjects of learning $[1$, p. 183]. Thus, building a learning process on the basis of dialogue as the most suitable for organizing productive, personal, professional-oriented contacts of the teacher and magistracy students is an essential prerequisite for implementing a personal approach in shaping the readiness of the future head of a comprehensive educational institution for strategic management.

Important place in our research is devoted for the debate and discussion. They represent an organized discussion of a variety of problems that can 
give them more weight and cause cognitive interest. Debatable technologies include:

- debates (formal discussion, which is based on the speeches of the representatives of the two rival teams (affirmation and denial of the problem issue). The debate is used to discuss topics for which there are opposing views of scholars;

- dispute (kind of discussion, public discussion of one or another problem that is important for students, which is usually prepared in advance and is connected with real life, own experience of participants);

- round table (involves a discussion in which a small group of magistracy students (up to 5 people) takes part with equal rights for a discussion of a particular issue. Each participant of the round table has the same right to express his or her own opinion, and the required condition of participation in the discussion is the necessity of the argumentation of the personal point of view of the participants);

- meeting of the expert group (or "panel discussion" is used to demonstrate different views on a particular problem, which involves discussion of the chosen issue by a small group of 4-6 students). The panel discussion takes place in two stages: discussion of the problem by all microgroup participants; presentation of the position of the microgroup in speeches. At the same time, discussion of this position with the whole group is not provided);

- forum (a discussion in which students consider a certain problem and produce a position, which is then discussed with other students);

- "aquarium" (discussion used in the work with material, the content of which is associated with contradictory approaches, conflicts, differences);

- "brainstorming" (discussion, the purpose of which is the generation of alternative nonconventional solutions of the problems studied, the formation of new, original ideas);

- synectics (a discussion that uses analogies from other branches of knowledge).

Comprehensive application of different forms of discussion enables to effectively solve a number of issues for the future heads of comprehensive educational institutions: to form the ability to analyze managerial situations, develop verbal and nonverbal communicative skills, expand the field of awareness of possible ways of communication in different situations of business interaction, form listening skills, be able to prove own views, defend own positions, interact productively with other participants of the discussion. 
The above-mentioned technologies are most optimal for expressing own views and beliefs, argued negation, refutation of the opponent's wrong position, formation of logic and evidence of judgment, summary and accuracy of presentation, advocacy of the own thoughts, creative cooperation, stimulation of tolerance and reflection.

Applying of the mentioned dialogic-debatable learning technologies will enable more deep and versatile approach to the process of forming the readiness of the future head of the educational institution for strategic management in the conditions of master's degree, namely: to increase the level of motivation of students for management activities; to form activity, initiative, ability to work in a team; to develop creativity in the activity and responsibility for the profession; to form the managerial competencies necessary for the manager in the implementation of strategic management, etc.

\section{Simulation training technology}

The specificity of simulation training technology is in the simulation in the learning process the relationships and conditions of real life. At the heart of simulation technology is imitation or simulation game, that is, the reproduction of various processes occurring in the real system in terms of learning. The construction of models and the organization of work of master's degree students with them give an opportunity to reflect on the educational process various types of professional context and to form professional experience in conditions of quasi-professional activity. Quasi-professional activity is "such a student's activity, which in its form is educational, but in the content is a professional one. It involves the transformation of the content and forms of educational activities in their adequately generalized content and forms of professional activity" [3]. Thus, simulation training technologies are a kind of "training laboratory" in which the real situation of professional activity is modeled, participants of the experiment can apply their decision-making skills to a simulated situation.

All imitation technologies are classified by the presence of roles. On this basis, they are divided into gaming and non-gaming. The advantages of simulation training techniques for gaming and non-gaming education are: the formation of practical managerial skills by future heads of the educational institutions; high comprehensiveness of the material, the formation of general and professional knowledge, skills necessary for strategic management at the expense of the created simulation environment of the professional environment. 
The application of gaming technologies in the context of our research is effective in terms of acquiring skills of practical experience by the magistracy students, the formation of professional skills to act in managerial situations, with the activization and intensification of educational and cognitive activity of magistracy students taking place through the play of certain roles and imitation of professional activity - when actions in a game situation cease to be a game and reincarnate in practical activity (this is the purpose and meaning of simulation training).

Within the framework of the research, it is envisaged to use such gaming imitation technologies as situational role games, business games, training, internships (with the execution of an official role).

Situational role games provide an opportunity to simulate real situations that are inherent in the managerial activity of the head of a comprehensive educational institution. During the situational role-playing game, magistrants conduct intense mental work, collectively seek optimal solutions, using theoretical knowledge and acquired practical experience. The optimality of the process of forming the readiness of the future head of a comprehensive educational institution for strategic management is largely ensured through the use of situational role games in the educational process.

Effective game technology when forming the readiness of the future head of a comprehensive educational institution for strategic management has become a business game. The use of business games in training allows one to get the educational process closer to practical activities, take into account the realities, make decisions in situations of conflict situations, defend own positions, develop teamwork and team feeling among game participants, and get results in a very limited time. In specially created conditions, the future specialist processes the most diverse life and professional situations that allow him to form his worldview, defend his position, acquire professional knowledge and skills.

With the purpose of forming the readiness of the future head of the comprehensive educational institution for strategic management, a variety of games is provided: situation-role games ("Request", "Balloon", "Unsuccessful Plan", "Negotiations"), business games ("Defining the mission of a general educational institution", "Strategic planning of the development of a general educational institution", "The concept of development of a general educational institution of the future").

Modern conditions for the formation, development and functioning of comprehensive educational establishments set new requirements for 
the preparation of managers. One of the directions of improvement of the educational process of future heads of comprehensive educational institutions is the active use of trainings. Trainings is an organizational form of educational work, which, based on the experience and knowledge of its participants, ensures the effective use of various pedagogical methods, in particular, active, by creating a positive emotional atmosphere in the group, and is directed to obtaining the acquired skills and life competencies [9, p. 209] whose effectiveness in the development of professionally meaningful skills is reflected in the psychological and pedagogical literature (P. Bavina, N. Volkova, S. Kozhushko, L. Lukianova, V. Saakova, S. Strashko, O. Shapran and others).

In order to form future heads of comprehensive educational institutions of entrepreneurial, forecasting, diagnostic and analytical, administrative and managerial and reflexive and regulatory skills, we have developed an author's training aimed at helping each student to understand his own drawbacks in developing managerial skills, identifying and assessing potential opportunities, implementation obtained knowledge in practice. The central idea of the training is the concept of strategic management. Author's training is a cycle of group sessions, in which students are offered individual and group tasks and exercises aimed at the formation of knowledge, skills and professional qualities of the manager in the process of strategic management on the training stage.

The objectives of the author's training are: to develop the motivation and desire of students to improve their readiness for strategic management; to form a strategic outlook; develop professionally important qualities; to form a positive experience of strategic activity of magistracy students in simulated situations of professional activity; train students to overcome professional difficulties.

The following content components are presented in the training program on readiness for strategic management: the formation of individual and group performance (formation of emotional cohesion in the group, trust and openness between participants, development of skills of group interaction, which ensures the possibility of further successful work), the development of professionally important qualities of the head of a comprehensive educational institution that is significant for the implementation of strategic management (includes a set of exercises and procedures designed for the formation of the following professional qualities of the head of a comprehensive educational institution that are significant for the implementation 
of strategic management: persistence, risk aversion, assertiveness, adaptability, entrepreneurship, and ability to reflect), elaboration of behavior by future heads of comprehensive educational institutions in simulated situations of strategic orientation (goal: work out of behavior skills in simulated managerial situations of strategic orientation, which require the organization of efficient collective work; studying the processes of making strategic decisions by the group and developing mastery skills of convincing action), completing training sessions (using exercises and procedures aimed at providing participants with the opportunity to assess the quality of their work).

It is advisable, in our opinion, to focus on such simulation training technology as internship with the execution of an official role - the form and method of active learning of contextual type, in which the "model" is the very reality, and imitation mainly affects the implementation of a role (position). The main condition for internship is its implementation under the control of the organizer of certain actions in real working conditions. Internship provides the most complete approximation of the learning process to practical professional activities. Such technology is most often used in modern universities and is implemented through working and training practices.

We determine the internship of the future head of a comprehensive educational institution as a specially organized educational professional-oriented activity of the master's degree student, in which he implements the theoretical knowledge, skills and abilities, acquires experience of practical management work, shows personal professional qualities in accordance with the requirements of qualification level of training.

The tasks of the internship in the context of the problem under study are: deepening, expanding, integrating knowledge on the theory of strategic management; the formation of a master's degree students of the idea of the content, components and peculiarities of the implementation of the strategic plan of the comprehensive educational institution; studying the experience of using modern technologies of strategic management in a comprehensive educational institution; improvement of analytical and reflexive activity of magistracy students as strategists; formation of skills of possession of the mechanisms of implementation of the main functions of strategic management; the formation of adequate self-esteem and responsibility for the results of their work. Consequently, during the internship, future heads of comprehensive educational institutions are given the opportunity to comprehend, summarize and secure the knowledge of the theory of strategic 
management, acquired during the studying period, and identify the appropriate ways and means of their effective use in professional activities, to form and develop practical skills.

Internship arranges future leaders of comprehensive educational institutions with the necessary experience of professional-strategic activity and gives the opportunity to master the following strategic skills: to orient in the organizational structure and normative-legal documentation of a comprehensive educational institution; to orient in the theoretical bases of strategic management of a comprehensive educational institution; didactically transform the results of modern scientific research in order to use it in the strategic management of a general educational institution; independently design, implement, evaluate and correct the strategic process; possess methods of self-organization, self-education, self-development, improvement of oneself as a strategist; know a culture of communication and build relationships with colleagues in the process of developing and implementing a strategy for the development of a comprehensive educational institution; to find, accept and implement strategic decisions during the master's internship.

Thus, gaming technologies contribute to the formation of general-professional competencies, such as: to understand the essence and social significance of the future profession, to show steady interest in it; to organize own activities, proceeding from the purpose and ways of its achievement; to analyze the working situation, to carry out current and final control, to be responsible for the results of the work; to search the information necessary for the effective performance of professional tasks; work in a team, communicate effectively with colleagues, leadership, etc.

The basis of non-gaming simulation training technologies is the problem situation. In the process of its solving the activation of the intellectual activity of future leaders of comprehensive educational institutions is taking part, it also develops the skills of analysis and critical thinking, the ability to express personal point of views, thus forming the general and professional competencies necessary for the management and strategic management in particular.

Within the framework of our study, the following information and communication technologies of learning are important: case method (method of specific situations), "balint session", method of diaries, method 6-6, method of time restrictions, method of sudden prohibitions, method of new variants, absurd method. 
The use of non-gaming simulation training technologies can stimulate the individual activity of students, form a positive motivation for training; reduces the number of "passive" and non-confident students, and also provides high efficiency training and development of future specialists; allows the student to learn independently; analyze and investigate specific situations, close to real conditions; be able to make informed and correct decisions, improve own abilities.

Summing up the above, we believe that realization in the process of formation of the readiness of the future head of a comprehensive educational institution for strategic management in the conditions of the magistracy of simulation training technologies leads to positive motivational shifts for the magistracy students, gives them an opportunity to feel satisfaction from the awareness of their own growth and development, triggers the launch of internal mechanisms of self-development, self-realization and self-improvement in the varieties of educational activities, awareness of the need for personal restructuring, which is an important step in optimizing vocational training.

\section{Information and distance learning technologies}

Information and distance technologies are called for optimization and improvement of the efficiency of independent work of future heads of comprehensive educational institutions in the conditions of the magistracy. They are especially relevant in the process of organizing independent work in the conditions of the magistracy, because studying in the magistracy is based on the principles of the andragogical approach.

Technologies of information and distance learning consist of information and distance learning technologies. Information technology of distance learning is the technology of creating, transmitting and preserving educational materials, organizing and supporting the educational process through telecommunication. Distance learning technologies can be used not only in distance education, but also in other forms of education: full-time, parttime, external; act as elements of independent work in separate disciplines or blocks of disciplines intended to improve the educational level or qualification of individual students and / or groups of students.

We consider it necessary to focus attention on the fact that information and distance technologies envisage the interaction of teachers and students in the computer environment of communication. Speaking about "student dialogue 
with a computer, we mean not dialogue in its general sense, but educational and professional interaction in the system "teacher - student - computer", aimed at achieving certain goals" [5, p. 214]. In this case, it is a question of training, in which the teacher and student have the opportunity to widely use e-mail, electronic conferences and other resources of the Internet.

As part of the study, the use of such information-distant technologies as project technologies, Internet-oriented technologies (mentoring, pair training, e-mail, chat technology, webinar) is foreseen.

Project learning technology is based on the project method. The project method is based on an idea that reflects the essence of the concept "project". The project is the development of a plan, idea, detailed plan of a practical product [6]. In turn, the project method is "a complex method of learning that allows building a learning process based on the interests of students, gives them the opportunity to demonstrate autonomy in the planning, organization and control of their own educational and cognitive activity, the result of which is the creation of a real object, subject, creation of various kinds of theoretical product" [2, p. 29]. The essence of the project method is to achieve the didactic goal through a detailed development of a learning problem, which should end with a practical result (the project). During the work on the project, student acts as an active researcher, who is creatively working on solving the educational task. Project work contributes to the development of intellectual abilities, leadership qualities, develops the ability to work, to feel a member of the team.

The relevance of the design technology in working with future heads of comprehensive educational institutions is conditioned by its main tasks, which is to teach future managers to independently acquire knowledge and apply them to solve new cognitive and practical tasks; to promote the development of communicative abilities; expand the circle of communication; to instill the ability to use research methods: to collect and analyze information, to put forward hypotheses, to draw conclusions.

The purpose of the project technology is to stimulate the interest of future managers in the problems of implementing strategic management in educational institutions, which involve mastering a certain amount of knowledge and through project activity, which involves their solution, to develop managerial (business-forecasting, diagnostic-analytical, administrative-managerial, reflexive-regulatory) ability to apply the acquired knowledge in practice; the development of reflex (critical) thinking. 
In the context of this study, the approximate themes of the projects were identified: "Strategic management and risk", "Strategic management in scientific activity", "Negative consequences of strategic management", "Communication in strategic management", "Japanese, American and European model of strategic management" "Readiness of the head of a comprehensive educational institution for strategic management" and others.

One of project methods is a method of telecommunication training projects. Under the telecommunication training project is understood the common educational and cognitive activity of partner students, organized on the basis of computer telecommunications, which has a common problem, purpose, agreed methods and methods of solving the problem, aimed at achieving a common result. An important feature of a telecommunication training project is its interpersonal nature, since solving a problem that is implicit in any project always requires integrated knowledge.

Conducting of telecommunication training projects is aimed at: 1) developing the students' ability to work analytically and creatively with various sources of information, to set and solve problems in the process of work, to design actions in accordance with the inclination and abilities, to show the results of their activities with the help of various means; 2) creating a picture of the world for students by expanding and deepening knowledge about specific problems; 3) their acquisition of information and communication technologies at a higher level; 4) the formation of their own life experience in interaction with the outside world [7, p. 18].

Taking into account the above mentioned, with the purpose of forming the readiness of the future head of a comprehensive educational institution for strategic management in the conditions of the master's degree, we have developed and proposed for magistracy students telecommunication educational project "Innovative strategies for the development of a comprehensive educational institution in the conditions of strategic management of the education system".

The specificity of Internet-oriented technologies is that they provide the teacher and students with the opportunity to select the sources of information needed in the educational process: basic information, located on Web-servers of the network; operative information, systematically sent to the student by e-mail according to the chosen mailing list; various databases of leading libraries, information, scientific and educational centers, higher educational establishments; information about textbooks, magazines, study guides, distributed through Internet-shops [4, p. 42]. 
Let us name the Internet-oriented technologies provided by our research:

1. A network mentor is a professional in a particular subject area that helps the student to independently master a particular topic both within and beyond the curriculum. This form of work is ideally suited for the Internet, as when communicating via e-mail or in chats, magistrants feel more free than in personal face-to-face communication with a teacher. Deferred communication allows more clearly formulating questions and answers to them.

2. Parallel training suggests that two students prepare a presentation on a specific topic (presentation of a project, presentation with a report at a conference, etc.). The task for them is to show each other their own presentations and discuss their quality, ask as many questions as possible, trying to predict what situations may arise during the forthcoming officially scheduled presentation. After previewing and discussing, they correct their own materials, help each other in their refinement (processing).

3. E-mail is defined as a system for storing and forwarding messages between people having access to a computer network. It is worth noting that using e-mail the teacher can immediately distribute the answers that most often occur, not only to those who asked, but also to everyone else; it is possible to remove barriers that interfere with those who are taught to ask questions related to problems that lie beyond the discipline under study; it is possible to change the management of the educational process qualitatively, giving an opportunity to distribute the results of attestation, disposition and other administrative information in advance; students can explain the reasons for their absence at classes, report illness, send current reports from practice in remote locations, and so on. This kind of use of e-mail creates a feeling of personal contact with a teacher.

4. The chat technology is a means of implementing the interaction of future professionals in synchronous mode, that is, online. In the process of forming the readiness of the future head of a comprehensive educational institution to strategic management, it is advisable to combine voice and text types of chat that both have certain disadvantages and advantages. So, among the benefits of text chat there are highlighted: the ability to use a text chat at home; introduction of innovative technologies at classes; increasing the motivation of students to prepare for the implementation of strategic management; minimal technological equipment; ease of use; the ability to record chat for the purpose of speech analysis. As disadvantages it may be named: the chaos of a text chat (jumping from thought to thought, deviation 
from the topic); the difficulty in determining the cause of an error that can be made mechanically during printing or through conditional abbreviations; given the low level of automatic typing skills, students may not be able to keep up with the logic of communication.

5. The webinar technology involves holding classes in the virtual classroom, which provides the necessary functionality for distance learning of future heads of comprehensive educational institutions. In this case, the virtual classroom is a program that allows one to conduct classes online in real time. The virtual class is actually an analogue to a regular classroom audience. The teacher can, as in the normal class, show students additional materials. Students can freely interact with a teacher by asking him questions through chat or voice inclusions.

As part of our research, the use of webinar technology is organized through invitations for magistracy students to meet with experts who are professionals in the field of strategic management. The instructor in advance informs the masters about the upcoming meeting, informs the name of the expert, his professional interests and competencies, as well as the time of the meeting. As a rule, in order to save time during an online meeting, students prepare their own questions in advance and pass them through a teacher to an expert. The expert receives questions, analyzes them and takes them into account when preparing for a meeting with students, which helps him to better orient in their knowledge/ignorance. Let us name the topics of webinars provided by our research: "Strategic management of the educational institution: own experience", "Strategic management of the educational institution: methodological support".

Modern information and distance technologies allow to individualize and intensify the educational process. Thus, lectures containing material which perception does not require additional discussions can be prepared electronically, displayed on a local network, on the Internet. The abstracts of lectures can be supplemented by collections of articles, additional materials, addressed to specific students. Individual training as such is realized mainly through technologies such as e-mail, which provide communication between a student and a teacher in a private form. Chat technology, a telecommunication training project, webinars allow both operational collective discussions, and long-term virtual seminars.

The indicated teaching technologies contribute to the formation of value and moral and spiritual orientations of future specialists, as they provide 
their active interaction with each other and teacher, equal partnership relations, tolerance and respect in relation to their opponent.

\section{Conclusions}

Summarizing the above, let us note that the research substantiates the technological support of the process of forming the readiness of the future head of a comprehensive educational institution in a master's degree conditions, which includes a set of dialogic-debatable, simulation training and information-distance learning technologies.

The advantages of dialogic-debatable technologies of training, which provide the students with a clear idea, where and how in the near future can be used previously obtained knowledge are: ability to generate, new ideas, creative thinking, competently work with information (ability to collect, process, analyze); quality of putting forward hypotheses, formulate problems; the ability to make their own conclusions from similar or alternative points of view; ability to communicate in different social groups; the ability to work collectively, to prevent conflict situations or to be able to professionally solve them.

The expediency of simulation training technologies is substantiated, which imitating the actual activity of the head of a comprehensive educational institution provide the formation of professional management skills in an artificially created environment. They provide the organization by the teacher developing and comfortable environment for each magistracy student, the constant development of the group to the level of the true team. The simulation training technologies contribute to the improvement of the quality of the professional training of future heads of comprehensive educational institutions with the formation of readiness for strategic management by creating the conditions for simulation of professional activity, the game nature of training in solving problem situations.

The advantages of information and distance technologies for the formation of the readiness of the future head of a comprehensive educational institution for strategic management are established. They provide educational and professional interaction in the system "teacher - student - computer", namely: individualization and activation of the educational process in the conditions of the magistracy; development of creative and intellectual abilities of magistracy students through the open and free use of all educational resources and programs, including those available on the Internet. 


\section{References:}

1. Volkova, N.P. (2005) Profesiino-pedahohichna komunikatsiia: teoriia, tekhnolohiia, praktyka [Professional-pedagogical communication: theory, technology, practice]. Dnipropetrovsk: DNU Publ., 304 p. (in Ukrainian).

2. Herasymchuk, O. (2008) E-learning. Tekhnolohii elektronnoho navchannia [E-learning technologies]. Lutsk, 430 p. (in Ukrainian).

3. Demchenko I.I. Teoretychni osnovy kvaziprofesiinoi pidhotovky maibutnoho vchytelia pochatkovoi shkoly do profesiinoi diialnosti v umovakh osvitnoi inkliuzii [Theoretical foundations of quasi-professional preparation of the future teacher of elementary school to professional activity in the conditions of educational inclusion]. Access mode: http://dspace.udpu.org.ua:8080/jspui/bitstream/6789/889/1/ KVASIPROF_tesy.pdf (in Ukrainian).

4. Zakharova, I.H. (2010) Informatsionnye tekhnolohii v obrazovanii. 6-e izd. [Information technologies in education. $6^{\text {th }}$ ed.]. Moskva : Akademiia Publ., $192 \mathrm{p}$. (in Russian).

5. Nakhod, S.A. (2014) Interaktyvni tekhnolohii u formuvanni prohnostych-nykh umin maibutnikh fakhivtsiv [Interactive technologies in shaping the predictive skills of future specialties]. Naukovi zapysky Berdianskoho derzhavnoho pedahohichnoho universytetu. Pedahohichni nauky [Scientific notes of the Berdyansk State Pedagogical University. Pedagogical Sciences], issue 3, pp. 211-217 (in Ukrainian).

6. Rohacheva, E.Yu. (2004) Pedahohicheskoe tvorchestvo Dzh. Diui v chikahskii period [The pedagogical work of J. Dewey in the Chicago period]. Pedahohika [Pedagogy], no. 5, pp. 90-96 (in Russian).

7. Svyrydiuk, T.V., Vedyshcheva, O.V. \& Ivaniuk, A.I. (2014) Telekomunikatsiini proekty yak zasib mizhkulturnoho spilkuvannia [Telecommunication projects as a means of intercultural communication]. Pedahohuchyi poshuk [Pedagogical search], no. 3 (83), pp. 17-19 (in Ukrainian).

8. Selevko, H.K. (2005) Entsiklopediia obrazovatelnykh tekhnolohii. V 2-kh t. [Encyclopedia of educational technologies : in 2 volumes]. Moskva, Narodnoe obrazovanie Publ., part 1, 556 p. (in Russian).

9. Strashko, S., Sliva, M. \& Kaliuzhnyi, Ya. (2011) Treninh yak orhanizatsiina forma navchalno-vykhovnoi roboty [Training as an organizational form of educational work]. Metodyka vykladannia pryrodnychykh dystsyplin $u$ vyshchii shkoli [Methodology of teaching natural sciences in high school]. Poltava : Astaraia Publ., pp. 209-211 (in Ukrainian).

10. Sysoeva, E. (2016) Interaktivnye tekhnolohii obucheniia v sisteme pov-ysheniia kvalifikatsii pedahohov [Interactive learning technologies in the system of advanced training of pedagogues]. Cheboksary, Interaktivplius Publ., 20 p. (in Russian). 